\title{
Hydrolytic enzymes and lectin-binding activity of black-pigmented anaerobic rods
}

\author{
Daniel Grenier, Sonia Labbé, Christian Mouton and Denis Meyrand
}

Author for correspondence: Daniel Grenier. Tel: +1 4186567341 . Fax: + 14186562861.

Groupe de Recherche en Ecologie Buccale, Faculté de Médecine Dentaire, Université Laval, Québec (Québec), Canada G1K 7P4

\begin{abstract}
Recent taxonomic studies on black-pigmented anaerobic rods, a group of bacteria found on mucosal surfaces of humans and animals, led to the subdivision of existing species and to the creation of new species. The aim of this study was to characterize all 11 currently recognized species of blackpigmented bacteria ( 55 strains) for their ability to hydrolyse a variety of natural and synthetic substrates and for their lectin reactivity. Although most of the strains demonstrated some activity against proteinaceous substrates, Porphyromonas gingivalis was the only species able to hydrolyse type I collagen. Most strains possessed glycylprolyl protease activity, elastase-like activity and phospholipase $C$ activity, whereas trypsin-like activity was restricted to $P$. gingivalis, Porphyromonas salivosa and Bacteroides macacae. $\beta$-Lactamase activity was demonstrated in five strains belonging to the saccharolytic group. The lectin reactivity of the bacteria was determined by a dot-blot procedure using horseradish-peroxidase-conjugated lectins. Three lectins, LOTUS A, RCA-I and ConA, failed to react with any of the bacteria tested. WGA reacted strongly with the cell surface of human biotypes of asaccharolytic black-pigmented bacteria ( $P$. gingivalis, Porphyromonas asaccharolytica and Porphyromonas endodontalis) and Prevotella intermedia. The animal biotype strains of $P$. gingivalis showed a higher affinity for SBA and PNA than for WGA.
\end{abstract}

Keywords: Porphyromonas spp., Prevotella spp., Bacteroides spp., lectin-binding activity, hydrolytic activity

\section{INTRODUCTION}

Black-pigmented anaerobic rods include a number of Gram-negative bacterial species isolated from mucosal surfaces of humans and animals. Although some species have yet to be reclassified, recent taxonomic studies recognize two genera: Porphyromonas for the asaccharolytic group and Prevotella for the saccharolytic group (Shah \& Collins, 1988, 1990). Several species of blackpigmented anaerobic bacteria are recovered from the oral cavity (van Winkelhoff et al., 1988). More specifically, Porphyromonas gingivalis and Prevotella intermedia are found in high numbers in periodontal pockets from patients with periodontal disease (Slots \& Listgarten, 1988; van Winkelhoff $e t$ al., 1988). These two species, which possess numerous virulence determinants (Holt \& Bramanti, 1991; Mayrand et al., 1991), are among a group of about

Abbreviation: HRP-lectin, horseradish-peroxidase-conjugated lectin (abbreviations for chromogenic substrates and lectins are defined in Methods). ten bacterial species for which there are data that associate them with periodontal disease (Tanner, 1991).

Black-pigmented bacteria produce a variety of hydrolytic enzymes which are active against natural substrates and synthetic chromogenic compounds (Seddon \& Shah, 1989; Suido et al., 1986, 1988). These extracellular and cell-associated hydrolytic activities may play a role in bacterial pathogenicity and may also represent an important criterion for bacterial identification. Indeed, $P$. gingivalis is the only black-pigmented bacterial species, of human origin, able to hydrolyse the synthetic chromogenic peptide $N$ - $\alpha$-benzoyl-DL-arginine- $p$-nitroanilide, which is the specific target for trypsin-like activity (Laughon et al., 1982). Most studies on the hydrolytic activities of black-pigmented bacteria have been carried out on Porphyromonas spp. and Pr. intermedia.

Lectins are non-immune proteins or glycoproteins with selective carbohydrate reactivity. These molecules represent potential tools for the characterization of bacterial cell surfaces as well as for the identification of clinical 
Table 1. Bacterial strains and their isolation site

\begin{tabular}{|c|c|c|}
\hline Species & Strain & Isolation site \\
\hline \multicolumn{3}{|l|}{ Porpbyromonas gingivalis } \\
\hline \multirow[t]{17}{*}{ Human isolates } & ATCC 33277 & Gingival sulcus (human) \\
\hline & ATCC 49417 & Subgingival plaque (human periodontitis) \\
\hline & W83 & Clinical specimen (human) \\
\hline & W50 & Clinical specimen (human) \\
\hline & W50/BR 1 & Brown colonial variant from W50 \\
\hline & W50/BE1 & Beige colonial variant from W50 \\
\hline & $\mathrm{BH} 18 / 10$ & Subgingival plaque (human periodontitis) \\
\hline & 381 & Subgingival plaque (human periodontitis) \\
\hline & LB13D-2 & Subgingival plaque (human periodontitis) \\
\hline & HW24D-5 & Subgingival plaque (human periodontitis) \\
\hline & OMG 406 & Subgingival plaque (human periodontitis) \\
\hline & HG1020 & Subgingival plaque (human periodontitis) \\
\hline & A7A1-28 & Subgingival plaque (human periodontitis) \\
\hline & $23 \mathrm{~A} 4$ & Subgingival plaque (human periodontitis) \\
\hline & 17 A 3 & Subgingival plaque (human periodontitis) \\
\hline & JKG 1 & Oral cavity (human) \\
\hline & $16-1$ & Subgingival plaque (human juvenile periodontitis) \\
\hline \multirow[t]{9}{*}{ Animal isolates } & 3492 & Gingival margin (cat) \\
\hline & Chat 1.1 & Gingival margin (cat) \\
\hline & B 243 & Subgingival plaque (squirrel monkey) \\
\hline & Т 22 & Subgingival plaque (cynomolgus monkey) \\
\hline & Chien 4.2 & Gingival margin (dog) \\
\hline & D2-9 & Gingival margin (dog) \\
\hline & Loup 1.1 & Gingival margin (wolf) \\
\hline & Coyote 1.2 & Gingival margin (coyote) \\
\hline & Ours 3-1 & Gingival margin (bear) \\
\hline \multirow[t]{3}{*}{ Porpbyromonas asaccharolytica } & ATCC 27067 & Leg wound (human) \\
\hline & ATCC 25260 & Empyema (human) \\
\hline & BM4 & Dental plaque (human) \\
\hline \multirow[t]{3}{*}{ Porphyromonas endodontalis } & ATCC 35406 & Infected root canal (human) \\
\hline & H 11 a-e & Infected root canal (human) \\
\hline & BN 11 a-f & Infected root canal (human) \\
\hline \multirow[t]{3}{*}{ Porpbyromonas salivosa* } & 3313 & Gingival margin (cat) \\
\hline & 3420 & Gingival margin (cat) \\
\hline & NCTC 11632 & Gingival margin (cat) \\
\hline \multirow[t]{7}{*}{ Prevotella intermedia } & A TCC 25611 & Empyema (human) \\
\hline & $\mathrm{MS} / 5 \mathrm{~B} / 367$ & Subgingival plaque (human) \\
\hline & BH $20 / 30$ & Subgingival plaque (human) \\
\hline & NCTC 9336 & Vincent's angina (human) \\
\hline & $\mathrm{Cg} 1265$ & Subgingival plaque (human) \\
\hline & G8-9K-3 & Subgingival plaque (human) \\
\hline & $5 \mathrm{~W} 2$ & Subgingival plaque (human) \\
\hline \multirow[t]{2}{*}{ Prevotella denticola } & ATCC 33185 & Maxillary antrium (human) \\
\hline & LD6 & Subgingival plaque (human) \\
\hline \multirow[t]{3}{*}{ Prevotella melaninogenica } & ATCC 25845 & Sputum (human) \\
\hline & $\mathrm{Cg} 1198$ & Oral cavity (human) \\
\hline & VP1 4196 & Oral cavity (human) \\
\hline \multirow[t]{2}{*}{ Prevotella loescheii } & ATCC 15930 & Gingival sulcus (human) \\
\hline & SA 19 & Oral cavity (human) \\
\hline \multirow[t]{2}{*}{ Prevotella corporis } & ATCC 33547 & Cervical swab (human) \\
\hline & HG119 & Unknown \\
\hline \multirow[t]{2}{*}{ Bacteroides macacae } & ATCC 33141 & Subgingival plaque (monkey) \\
\hline & MD1-21 & Subgingival plaque (monkey) \\
\hline \multirow[t]{2}{*}{ Bacteroides levii } & ATCC 29147 & Rumen (bovine) \\
\hline & VPI 12466 & Mastitis (bovine) \\
\hline
\end{tabular}

* Formerly Bacteroides salivosus (Love et al., 1992). 
isolates (Slifkin \& Doyle, 1990). For example, lectin reactivity is a rapid and effective means for the differentiation of species of Bacillus (Cole et al., 1984) as well as of members of the family Neisseriaceae (Doyle et al., 1984). To our knowledge, there are no published data concerning the lectin-binding activity of black-pigmented bacteria.

In the present study, we included all the currently known species of black-pigmented anaerobic rods and characterized them for their ability to hydrolyse a variety of natural and synthetic substrates as well as for their reactivity with lectins possessing different specificities.

\section{METHODS}

Bacteria and growth conditions. A total of 55 bacterial strains, representing all 11 currently recognized species of blackpigmented anaerobic rods, were used in the study. The bacteria and their isolation site are listed in Table 1. Bacterial cells were cultivated in brain heart infusion broth (BBL Microbiology Systems) supplemented with haemin $\left(10 \mu \mathrm{g} \mathrm{ml}^{-1}\right)$ and vitamin $\mathrm{K}$ $\left(1 \mu \mathrm{g} \mathrm{ml}^{-1}\right)$. Cultures were incubated for $3 \mathrm{~d}$ in an anaerobic chamber $\left(\mathrm{N}_{2} / \mathrm{H}_{2} / \mathrm{CO}_{2}, 80: 10: 10\right.$, by vol.) at $37^{\circ} \mathrm{C}$.

Determination of hydrolytic activity on natural substrates. A variety of hydrolytic activities were assayed, in a plate culture assav, according to previously described procedures: caseinase (Sokol et al., 1979), gelatinase (Syed, 1976) and hyaluronidase (Grenier \& Michaud, 1993). The recent method for detection of hyaluronidase activity is based on the formation of a waterinsoluble salt between hyaluronic acid and the polyanion cetylpyridinium chloride. Collagen degradation was determined by assaying for the production of lower-molecular-mass fragments by SDS-PAGE, using the Laemmli buffer system (Laemmli, 1970). Briefly, bacterial cells $\left(50 \mu \mathrm{l} ; \mathrm{OD}_{660} 2 \cdot 0\right.$ in Tris/ $/ \mathrm{HCl}$ ) were incubated in the presence of $8 \mathrm{mM}$ dithiothreitol-100 mM Tris/ $\mathrm{HCl}(50 \mu \mathrm{l})$ and acid-soluble type I collagen $\left(25 \mu \mathrm{l}, 1 \mathrm{mg} \mathrm{ml}^{-1}\right.$ in $0.01 \%$ acetic acid). After $2 \mathrm{~h}$ at $37^{\circ} \mathrm{C}$, the assay mixtures were boiled for $10 \mathrm{~min}$ in the presence of an equal volume of solubilization buffer $[125 \mathrm{mM}$ Tris $/ \mathrm{HCl}$ $(\mathrm{pH} 6.8), 2 \%, \mathrm{w} / \mathrm{v}, \mathrm{SDS}, 2 \%, \mathrm{v} / \mathrm{v}, 2$-mercaptoethanol] and run on SDS-PAGE $(8 \%, w / v$, acrylamide). The proteins were stained with Coomassie Brilliant Blue. Assays were run in triplicate to ensure reproducibility.

Determination of hydrolytic activity on chromogenic substrates. (i) Peptidase. Whole bacterial cells were tested for peptidase activity according to a slight modification of the procedure described by Pederson \& Lamberts (1990). The following synthetic chromogenic peptides were used: $N-\alpha$ benzoyl-DL-arginine- $p$-nitroanilide (BAPNA; trypsin-like activity), glycyl-L-proline- $p$-nitroanilide (GPPNA; glycylprolyl protease activity), $\quad N$-succinyl-L-alanyl-L-alanyl-L-prolyl-Lphenylalanine- $p$-nitroanilide (SAAPPPNA; chymotrypsin-like activity) and $N$-succinyl-L-alanyl-L-alanyl-L-alanyl-p-nitroanilide (SAAAPNA; elastase-like activity). Briefly, a $1 \%$ $(\mathrm{w} / \mathrm{v})$ Noble agar solution in $100 \mathrm{mM}$ Tris/ $\mathrm{HCl}$ buffer $(\mathrm{pH} 7 \cdot 8)$ was boiled and then the chromogenic peptide was dissolved to a final concentration of $0 \cdot 1 \%$. The solution was cooled to $55^{\circ} \mathrm{C}$ and wells of a flat-bottomed microtitre plate were filled with $125 \mu \mathrm{l}$ of the mixture. After solidification of the gel, the plates were sealed with a plastic wrap and kept at $4{ }^{\circ} \mathrm{C}$ until used (for up to one month). Aliquots $(50 \mu \mathrm{l})$ of the bacterial suspensions $\left(\mathrm{OD}_{660} 2 \cdot 0\right.$ in Tris/ $\mathrm{HCl}$ supplemented with $5 \mathrm{mM}$ dithiothreitol) were placed in wells containing the chromogenic peptides immobilized in the agar gel, and the plate was incubated at $37^{\circ} \mathrm{C}$ for $4 \mathrm{~h}$. A positive reaction was indicated by the appearance of a yellow colour. Assays were run in triplicate to ensure reproducibility.

(ii) Phospholipase C. Phospholipase C activity was assayed using the synthetic chromogenic substrate $p$-nitrophenylphosphorylcholine (NPCC), based on the method described by Kurioka \& Matsuda (1976). The assay was carried out as for the peptidase activity except that NPCC was used at $0.25 \%$ and $60 \%(\mathrm{w} / \mathrm{v})$ sorbitol was included in the agar gel. After an incubation at $37^{\circ} \mathrm{C}$ for $3 \mathrm{~h}$, a positive reaction was indicated by the appearance of a yellow colour. Assays were run in triplicate to ensure reproducibility.

(iii) $\beta$-Lactamase. $\beta$-Lactamase activity was tested using a chromogenic cephalosporin, nitrocefin (kindly provided by $\mathrm{Dr}$ J.-M. Lacroix, University of Florida, Gainesville, FL, USA), and based on the procedure of Bourgault \& Rosenblatt (1979). Briefly, $50 \mu \mathrm{l}$ nitrocefin $(0.05 \%$ in Tris $/ \mathrm{HCl})$ was mixed with $50 \mu \mathrm{l}$ bacterial cell extract (cell suspension at $\mathrm{OD}_{660} 2.0$ in Tris/ $/ \mathrm{HCl}$ and sonicated for $45 \mathrm{~s}$ ), and incubated at $37^{\circ} \mathrm{C}$ for $10 \mathrm{~min}$. A positive reaction was indicated by the appearance of a red colour. Assays were run in triplicate to ensure reproducibility.

Determination of lectin-binding activity. Six horseradishperoxidase-coupled lectins (HRP-lectins; Sigma) were used: LOTUS A (Tetragonolobus purpureas; specific for fucose residues), Con A (Canavalia ensiformis; specific for mannose residues), RCA-I (Ricinus communis; specific for galactose residues), PNA (Arachis hypogaea; specific for galactose residues), SBA (Glycine $\max$; specific for $N$-acetyl-D-galactosamine and galactose residues) and WGA (Triticum vulgaris; specific for $N$-acetyl-Dglucosamine residues). Powdered lectins were dissolved, to a concentration of $1 \mathrm{mg} \mathrm{ml}^{-1}$, in phosphate-buffered saline $\mathrm{pH} 6.8$ and stored at $-20{ }^{\circ} \mathrm{C}$ until used.

Aliquots $(5 \mu \mathrm{l})$ of bacterial suspensions $\left(\mathrm{OD}_{660} 0 \cdot 2\right.$, in Tris $\left./ \mathrm{HCl}\right)$ were applied to a nitrocellulose membrane and allowed to dry at $37^{\circ} \mathrm{C}$ for $1 \mathrm{~h}$. The membrane was incubated in $20 \mathrm{mM}$ Tris/ $\mathrm{HCl}$ (pH 7.5) $-0.5 \mathrm{M} \mathrm{NaCl}$ (TBS) containing $3 \%(\mathrm{w} / \mathrm{v}$ ) bovine serum albumin (BSA) for $1 \mathrm{~h}$ at room temperature with shaking. The nitrocellulose membrane was then transferred to TBS containing $1.5 \% \mathrm{BSA}$ and the HRP-lectin (final concentration $1 \mu \mathrm{g} \mathrm{ml}^{-1}$ ) under investigation. The membrane was incubated at room temperature for $2 \mathrm{~h}$ with shaking and then washed in TBS containing $0.05 \%$ Tween-20 $(6 \times 15 \mathrm{~min})$. The nitrocellulose membrane was stained with the Bio-Rad HRP colour development kit according to the manufacturer's instructions. Lectin labelling of bacteria was indicated by the appearance of a purple spot. Assays were run in triplicate to ensure reproducibility.

\section{RESULTS}

The ability of the black-pigmented anaerobic bacteria to degrade natural substrates is reported in Table 2. Except for one strain of Prevotella melaninogenica (ATCC 25845), all the other bacteria under investigation were capable of hydrolysing at least one of the two general proteinaceous substrates, casein or gelatin. Animal and human biotype strains of $P$. gingivalis were the only bacteria able to cleave acid-soluble type I collagen. Strain W50/BE1, a colonial variant of $P$. gingivalis $W 50$, had no hydrolytic activity against collagen. Using a new specific procedure for the detection of hyaluronidase activity, none of the bacterial strains under investigation were positive. 
Table 2. Hydrolytic activity of black-pigmented anaerobic rods on natural substrates

\begin{tabular}{|lcccc|}
\hline Species & \multirow{2}{*}{$\begin{array}{c}\text { No. of } \\
\text { strains } \\
\text { tested }\end{array}$} & \multicolumn{2}{l}{ Positive for hydrolysis of*: } \\
\cline { 4 - 5 } & & Casein & Gelatin & Collagen \\
\hline P. gingivalis & 17 & 17 & 17 & $16 \dagger$ \\
(human biotype) & & & & \\
P. gingivalis & 9 & 9 & 9 & 9 \\
(animal biotype) & & & & \\
P. asaccharolytica & 3 & 3 & 3 & 0 \\
P. endodontalis & 3 & 3 & 3 & 0 \\
P. salivasa & 3 & 3 & 3 & 0 \\
Pr. intermedia & 7 & 7 & 7 & 0 \\
Pr. denticola & 2 & 2 & 0 & 0 \\
Pr. melaninogenica & 3 & 0 & 2 & 0 \\
Pr. loescheii & 2 & 2 & 1 & 0 \\
Pr. corporis & 2 & 1 & 2 & 0 \\
B. macacae & 2 & 2 & 2 & 0 \\
B. levii & 2 & 2 & 2 & 0 \\
\hline
\end{tabular}

* All the strains were negative for hydrolysis of hyaluronic acid.

tThe negative result was obtained with the mutant strain W50/BE1.

Hydrolysis of a variety of chromogenic substrates by the black-pigmented anaerobic bacteria is reported in Table 3 . $P$. gingivalis (human and animal biotypes), Porphyromonas salivosa and Bacteroides macacae strains possessed trypsinlike activity. By contrast, the other black-pigmented bacteria as well as the $P$. gingivalis mutant W50/BE1 had no activity against the chromogenic peptide BAPNA. All the bacteria under investigation possessed glycylprolyl protease and phospholipase $\mathrm{C}$ activities. The phospho-
Table 4. Lectin-binding activity of black-pigmented anaerobic rods

\begin{tabular}{|lcccc|}
\hline Species & $\begin{array}{c}\text { No. of } \\
\text { strains } \\
\text { tested }\end{array}$ & $\begin{array}{c}\text { Positive reaction } \\
\text { with*: }\end{array}$ \\
\cline { 4 - 5 } & & PNA & SBA & WGA \\
\hline P. gingivalis & 17 & 0 & 0 & $16 \dagger$ \\
(human biotype) & & & & \\
$P$. gingivalis & 9 & 5 & 5 & 1 \\
(animal biotype) & & & & \\
$P$. asaccharolytica & 3 & 0 & 0 & 2 \\
$P$. endodontalis & 3 & 0 & 0 & 3 \\
$P$. salivosa & 3 & 0 & 0 & 0 \\
Pr. intermedia & 7 & 0 & 0 & 6 \\
Pr. denticola & 2 & 0 & 2 & 0 \\
Pr. melaninogenica & 3 & 0 & 0 & 0 \\
Pr. loescheii & 2 & 0 & 0 & 0 \\
Pr. corporis & 2 & 0 & 0 & 0 \\
B. macacae & 2 & 0 & 0 & 0 \\
B. levii & 2 & 0 & 0 & 0 \\
\hline
\end{tabular}

* All the strains gave a negative reaction with LOTUS A, ConA and RCA-I.

†The negative result was obtained with the mutant strain W50/BE1.

lipase $C$ activity of $P$. gingivalis was found to be highly sensitive to oxygen (data not shown). Chymotrypsin-like activity was detected in some species of black-pigmented bacteria, more particularly in the three strains of $P$. salivosa, but not in $P$. gingivalis. Except for $P$. gingivalis W50/BE1, P. salivosa 3420, Pr. melaninogenica Cg 1198, Prevotella corporis HG119 and both strains of Bacteroides

Table 3. Hydrolytic activity of black-pigmented anaerobic rods on chromogenic substrates

\begin{tabular}{|c|c|c|c|c|c|c|c|}
\hline \multirow[t]{2}{*}{ Species } & \multirow{2}{*}{$\begin{array}{l}\text { No. of } \\
\text { strains } \\
\text { tested }\end{array}$} & \multicolumn{6}{|c|}{ Positive for hydrolysis of: } \\
\hline & & BAPNA & GPPNA & SAAPPPNA & SAAAPNA & NPCC & Nitrocefin \\
\hline $\begin{array}{l}\text { P. gingivalis } \\
\text { (human biotype) }\end{array}$ & 17 & $16^{*}$ & 17 & 0 & $16^{*}$ & 17 & 0 \\
\hline $\begin{array}{l}\text { P. gingivalis } \\
\text { (animal biotype) }\end{array}$ & 9 & 9 & 9 & 0 & 9 & 9 & 0 \\
\hline P. asaccharolytica & 3 & 0 & 3 & 2 & 3 & 3 & 0 \\
\hline P. endodontalis & 3 & 0 & 3 & 1 & 3 & 3 & 0 \\
\hline$P$. salivosa & 3 & 3 & 3 & 3 & 2 & 3 & 0 \\
\hline Pr. intermedia & 7 & 0 & 7 & 1 & 7 & 7 & 1 \\
\hline Pr. denticola & 2 & 0 & 2 & 0 & 2 & 2 & 1 \\
\hline Pr. melaninogenica & 3 & 0 & 3 & 1 & 2 & 3 & 1 \\
\hline Pr. loescheii & 2 & 0 & 2 & 0 & 2 & 2 & 0 \\
\hline Pr. corporis & 2 & 0 & 2 & 0 & 1 & 2 & 2 \\
\hline B. macacae & 2 & 2 & 2 & 1 & 2 & 2 & 0 \\
\hline B. levii & 2 & 0 & 2 & 1 & 0 & 2 & 0 \\
\hline
\end{tabular}

* The negative result was obtained with the mutant strain W50/BE1. 
levii, the other bacteria included in the study possessed elastase-like activity. $\beta$-Lactamase activity was only detected in Pr. intermedia MS $/ 5 \mathrm{~B} / 367$, Prevotella denticola ATCC 33185, Pr. melaninogenica ATCC 25845 and Pr. corporis ATCC 33547 and HG119.

The lectin reactivity of the black-pigmented anaerobic bacteria was determined by a dot-blot procedure using HRP-lectins. This method was simple and gave excellent reproducibility. LOTUS A, RCA-I and ConA failed to react with any of the 55 bacterial strains. These lectins are specific for fucose, galactose and mannose residues, respectively. The results presented in Table 4 indicate that most strains belonging to the species $P$. gingivalis, $P$. asaccbarolytica, P. endodontalis, Pr. intermedia and Pr. denticola were capable of binding one or more lectins. The lectin from Triticum vulgaris (WGA) showed the highest reactivity with the black-pigmented anaerobic rods. This lectin, which is specific for terminal $N$-acetyl-D-glucosamine, reacted with the cell surface of human biotype strains of $P$. gingivalis (16/17), $P$. asaccharolytica (2/3), $P$. endodontalis (3/3) and Pr. intermedia (6/7). The non-reactive strain of human biotype $P$. gingivalis was the beige mutant (W50/BE1). Surprisingly, only one out of nine animal biotype strains of $P$. gingivalis reacted with WGA. On the other hand, five animal biotype strains showed a strong affinity for both SBA and PNA lectins. In all cases, incorporation of the competing carbohydrates in the lectin-binding assay reduced but did not completely prevent the reaction with the lectins.

\section{DISCUSSION}

Recent taxonomic work on black-pigmented anaerobic bacteria led to the subdivision of existing species and to the creation of new species (Shah \& Collins, 1988, 1990). In addition to contributing to bacterial virulence, hydrolytic activity and lectin reactivity may represent interesting properties for bacterial differentiation. Although there are several reports (Laughon et al., 1982; Pederson \& Lamberts, 1990; Seddon \& Shah, 1989; Suido et al., 1988, 1986) on the hydrolytic activities of black-pigmented bacteria, there are no recent studies which have included all the currently known species. Furthermore, to our knowledge, no studies have evaluated the potential of lectins for the differentiation of blackpigmented anaerobic bacteria and for the characterization of their cell surfaces. We thus tested all the species of black-pigmented anaerobic bacteria for their ability to hydrolyse a variety of natural and synthetic substrates as well as for their lectin reactivity.

The present investigation showed that $P$.gingivalis (human and animal biotypes) possesses a specific collagenase activity. Other asaccharolytic species such as $P$. endodontalis, $P$. asaccharolytica and $P$. salivosa, which are closely related to $P$. gingivalis, did not hydrolyse type I collagen. This is in agreement with previous reports suggesting that $P$. gingivalis is the only black-pigmented human oral bacterium able to degrade collagen (Mayrand \& Grenier, 1985; Sundqvist et al., 1987). Hyaluronidase activity has been previously reported for some black-pigmented bacteria including $P$. gingivalis (Seddon \& Shah, 1989). The specific assay used in the present study indicated that none of the black-pigmented bacterial isolates under investigation were capable of hydrolysing hyaluronic acid. As we recently suggested (Grenier \& Michaud, 1993), the high proteolytic activity of these bacteria coupled with the use of non-specific methods was probably responsible for the false positive reactions obtained in previous studies.

Using chromogenic substrates, it was found that trypsinlike activity was restricted to $P$. gingivalis (human and animal biotypes), B. macacae and $P$. salivosa. These results are in agreement with previous studies on the trypsin-like activity of black-pigmented bacteria (Laughon et al., 1982; Seddon \& Shah, 1989). The presence of elastaselike activity and phospholipase $C$ activity in blackpigmented bacteria, including $P$. gingivalis and $P r$. intermedia, was demonstrated here for the first time. These hydrolytic activities may represent additional virulence determinants for these suspected periodontopathogens.

Lectins with different specificities were chosen for characterization of the cell surface of black-pigmented bacteria. The results revealed a certain degree of homogeneity in the lectin-binding capacity of these species. The high reactivity of WGA with $P$. gingivalis human biotype, $P$. asaccbarolytica, $P$. endodontalis and Pr. intermedia suggests the presence of terminal $\mathrm{N}$-acetyl-D-glucosamine residues on the surfaces of these bacteria. As already demonstrated by Frasch (1980), in the case of Neisseria meningitidis and Neisseria gonorrboeae, lectin reactivity may be related to the $\mathrm{N}$-acetyl-D-glucosamine residues of lipopolysaccharides. Some differences in lectin reactivity between the animal and human biotype strains of $P$. gingivalis were observed, which suggest that these are variations in the cell envelope composition. Parent et al. (1986), using a serological approach, have already demonstrated the presence of unique antigens for both the animal and human biotypes. Several factors may influence the interactions between lectins and bacteria. These include lectin molecular mass, lectin accessibility and the involvement of hydrophobic group stabilization (Slifkin \& Doyle, 1990). This is well demonstrated by the fact that PNA, which is specific for galactose residues, reacted with several strains of animal biotype $P$. gingivalis, whereas a second lectin (RCA-I) with a similar specificity did not react.

$P$. gingivalis W50/BE1, a non-pigmented beige variant isolated from a chemostat-grown culture of strain W50, was found to be quite different from the wild-type strain. The mutant appeared to have lost collagenolytic, trypsinlike and elastase-like activities. In addition, the cell surface of strain W50/BE1 could not bind the WGA lectin. These results are in agreement with other studies indicating that there are major differences between the beige mutant and the wild-type strain (Marsh et al., 1989; McKee et al., 1988).

In conclusion, the present study has confirmed previous observations and provided new data on the hydrolytic activities of black-pigmented anaerobic bacterial species. 
The reactivity of selected lectins with some species of black-pigmented species was also demonstrated for the first time. However, the lectin-binding activity could not discriminate between the various species.

\section{ACKNOWLEDGEMENTS}

D. Fournier and J. Michaud are acknowledged for their excellent technical assistance. We are also grateful to G. Bourgeau for editorial assistance. This work was supported by the Medical Research Council of Canada.

\section{REFERENCES}

Bourgault, A. M. \& Rosenblatt, J. E. (1979). Characterization of anaerobic gram-negative bacilli by using rapid slide test for $\beta$ lactamase production. J Clin Microbiol 9, 654-656.

Cole, H. B., Ezzell, J. W., Keller, K. F. \& Doyle, R. J. (1984). Differentiation of Bacillus antbracis and other Bacillus species by lectins. J Clin Microbiol 19, 48-53.

Doyle, R. J., Nedjat-Haiem, F., Keller, K. F. \& Frasch, C. E. (1984). Diagnostic value of interactions between members of the family Neisseriaceae and lectins. J Clin Microbiol 19, 383-387.

Frasch, C. E. (1980). Role of lipopolysaccharide in wheat germ agglutinin-mediated agglutination of Neisseria meningitidis and Neisseria gonorrboeae. J Clin Microbiol 12, 498-501.

Grenier, D. \& Michaud, J. (1993). Evidence for the absence of hyaluronidase activity in Porpbyromonas gingivalis. J Clin Microbiol 31, 1913-1915.

Holt, S. C. \& Bramanti, T. E. (1991). Factors in virulence expression and their role in periodontal disease pathogenesis. Crit Rev Oral Biol Med 2, 177-281.

Kurioka, S. \& Matsuda, M. (1976). Phospholipase C assay using $p$ nitrophenylphosphorylcholine together with sorbitol and its application to studying the metal and detergent requirement of the enzyme. Anal Biochem 75, 281-289.

Laemmli, U. K. (1970). Cleavage of structural proteins during the assembly of the head of the bacteriophage T4. Nature 227, 680-685.

Laughon, B. E., Syed, S. A. \& Loesche, W. J. (1982). APIZYM system for identification of Bacteroides spp., Capnocytophaga spp., and spirochetes of oral origin. J Clin Microbiol 15, 97-102.

Love, D. N., Bailey, G. D., Collings, S. \& Briscoe, D. A. (1992). Description of Porpbyromonas circumdentaria sp. nov. and reassignment of Bacteroides salivosus (Love, Johnson, Jones, and Calverly, 1987) as Porphyromonas (Shah and Collins, 1988) salivosa comb. nov. Int J Syst Bacteriol 42, 434-438.

Marsh, P. D., McKee, A. S., McDermid, A. S. \& Dowsett, A. B. (1989). Ultrastructure and enzyme activities of a virulent and an avirulent variant of Bacteroides gingivalis W50. FEMS Microbiol Lett 59, 181-186.

Mayrand, D. \& Grenier, D. (1985). Detection of collagenase activity in oral bacteria. Can J Microbiol 31, 134-138.
Mayrand, D., Mouton, C. \& Grenier, D. (1991). Chemical and biological properties of cell surface components of oral blackpigmented Bacteroides species. In Periodontal Disease: Pathogens and Host Immune Responses, pp. 99-115. Edited by S. Hamada, S. C. Holt \& J. R. McGhee. Tokyo: Quintessence Publishing Co.

McKee, A. S., McDermid, A. S., Wait, R., Baskerville, A. \& Marsh, P. D. (1988). Isolation of colonial variants of Bacteroides gingivalis W50 with a reduced virulence. J Med Microbiol 27, 59-64.

Parent, R., Mouton, C., Lamonde, L. \& Bouchard, D. (1986). Human and animal serotypes of Bacteroides gingivalis defined by crossed immunoelectrophoresis. Infect Immun 51, 909-918.

Pederson, E. D. \& Lamberts, B. L. (1990). Detection of microbial trypsin-like enzymes by use of an agar gel. Microbios 63, 165-171.

Seddon, S. V. \& Shah, H. N. (1989). The distribution of hydrolytic enzymes among Gram-negative bacteria associated with periodontitis. Microb Ecol Health Dis 2, 181-190.

Shah, H. N. \& Collins, M. D. (1988). Proposal for reclassification of Bacteroides asaccharolyticus, Bacteroides gingivalis, and Bacteroides endodontalis in a new genus, Porphyromonas. Int J Syst Bacteriol 38, 128-131.

Shah, H. N. \& Collins, M. D. (1990). Prevotella, a new genus to include Bacteroides melaninogenicus and related species formerly classified in the genus Bacteroides. Int J Syst Bacteriol 40, 205-208.

Slifkin, M. \& Doyle, R. J. (1990). Lectins and their application to clinical microbiology. Clin Microbiol Rev 3, 197-218.

Slots, J. \& Listgarten, M. A. (1988). Bacteroides gingivalis, Bacteroides intermedius and Actinobacillus actinomycetemcomitans in human periodontal diseases. J Clin Periodontol 15, 85-93.

Sokol, P. A., Ohman, D. E. \& Iglewski, B. H. (1979). A more sensitive plate assay for detection of protease production by Pseudomonas aeruginosa. J Clin Microbiol 9, 538-540.

Suido, H., Nakamura, M., Mashimo, P. A., Zambon, J. J. \& Genco, R. J. (1986). Arylaminopeptidase activities of oral bacteria. J Dent Res 65, 1335-1340.

Suido, H., Eguchi, T., Tanaka, T. \& Nakamura, M. (1988). Identification of periodontopathic bacteria based upon their peptidase activities. Adv Dent Res 2, 304-309.

Sundqvist, G., Carlsson, J. \& Hănström, L. (1987). Collagenolytic activity of black-pigmented Bacteroides species. J Periodontal Res 22, 300-306.

Syed, S. A. (1976). A new medium for the detection of gelatinhydrolyzing activity of human dental plaque flora. J Clin Microbiol 3, 200-202.

Tanner, A. (1991). Microbial succession in the development of periodontal disease. In Periodontal Disease: Pathogens and Host Immune Responses, pp. 13-25. Edited by S. Hamada, S. C. Holt \& J. R. McGhee. Tokyo: Quintessence Publishing Co.

van Winkelhoff, A. J., van Steenbergen, T. J. M. \& de Graaff, J. (1988). The role of black-pigmented Bacteroides in human oral infections. J Clin Periodontol 15, 145-155.

Received 23 August 1993; revised 25 October 1993; accepted 17 November 1993. 